Supporting Information

\title{
Large polarization of $\mathrm{Li}_{4} \mathrm{Ti}_{5} \mathrm{O}_{12}$ lithiated to $\mathrm{O} \mathrm{V}$ at large
}

\section{charge/discharge rates}

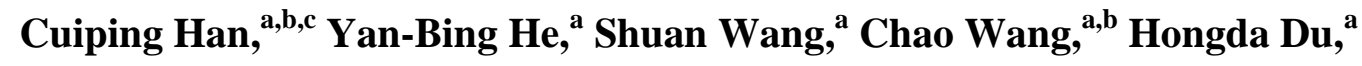 \\ Xianying Qin, ${ }^{\text {a }}$ Zhiqun Lin, ${ }^{\mathrm{c}, *}$ Baohua $\mathrm{Li}^{\mathrm{a}},{ }^{\mathrm{a}} *$ and Feiyu Kang ${ }^{\mathrm{a}, \mathrm{b}}$ \\ ${ }^{a}$ Engineering Laboratory for Next Generation Power and Energy Storage Batteries, \\ Engineering Laboratory for Functionalized Carbon Materials, Graduate School at Shenzhen, \\ Tsinghua University, Shenzhen 518055, China \\ ${ }^{b}$ Laboratory of Advanced Materials, School of Materials Science and Engineering, Tsinghua \\ University, Beijing 100084, China \\ ${ }^{c}$ School of Materials Science and Engineering, Georgia Institute of Technology, Atlanta, GA \\ 30332, USA
}

E-mail address:

libh@mail.sz.tsinghua.edu.cn and zhiqun.lin@mse.gatech.edu, 
Table S1. Reported specific capacities of LTO anode within the extended voltage range

\begin{tabular}{|c|c|c|c|}
\hline Sample & $\begin{array}{l}\text { Voltage } \\
\text { range }\end{array}$ & Specific capacities & Capacity retention \\
\hline $\begin{array}{ll}\mathrm{Al}_{2} \mathrm{O}_{3} \quad \text { Coated } & \mathrm{Li}_{4} \mathrm{Ti}_{5} \mathrm{O}_{12} \\
\text { Electrode } & {[\mathrm{S} 1]}\end{array}$ & $2.5-0.01 \mathrm{~V}$ & $\begin{array}{l}194 \mathrm{mAhg}^{-1} \text { at } 35 \mathrm{mAg}^{-1} ; \\
134 \mathrm{mAhg}^{-1} \text { at } 175 \mathrm{mAg}^{-1}\end{array}$ & $\begin{array}{l}95 \% \text { after } 100 \text { cycles } \\
\text { at } 88 \mathrm{mAg}^{-1}\end{array}$ \\
\hline $\begin{array}{l}\mathrm{ZnO} \quad \text { coated } \mathrm{Li}_{4} \mathrm{Ti}_{5} \mathrm{O}_{12} \\
\left(\left(\mathrm{Li}_{4} \mathrm{Ti}_{5} \mathrm{O}_{12}\right)_{100} /(\mathrm{ZnO})_{6}\right)\end{array}$ & $3.0-0.01 \mathrm{~V}$ & $\begin{array}{l}\sim 260 \mathrm{mAhg}^{-1} \text { at } 0.5 \mathrm{C} \\
\sim 220 \mathrm{mAhg}^{-1} \text { at } 1 \mathrm{C} \\
\sim 195 \mathrm{mAhg}^{-1} \text { at } 2 \mathrm{C} \\
\sim 195 \mathrm{mAhg}^{-1} \text { at } 4 \mathrm{C}\end{array}$ & 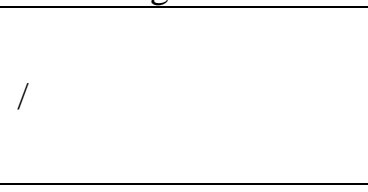 \\
\hline $\begin{array}{l}\mathrm{Li}_{4} \mathrm{Ti}_{4.95} \mathrm{Nb}_{0.05} \mathrm{O}_{12} \\
\text { synthesized by solid-state } \\
\text { method }{ }^{[\mathrm{S} 3]}\end{array}$ & $2.0-0.0 \mathrm{~V}$ & $\begin{array}{l}\text { 1st, 28th and 53rd discharge } \\
\text { capacity at } 0.1 \mathrm{C} \text { are } 342.9,202.7 \\
\text { and } 199.6 \mathrm{mAhg}^{-1} \text {, respectively }\end{array}$ & $\begin{array}{l}58.2 \% \text { after } 53 \text { cycles } \\
\text { at } 0.1 \mathrm{C}\end{array}$ \\
\hline $\begin{array}{l}\mathrm{Li}_{4} \mathrm{Ti}_{4.95} \mathrm{Nb}_{0.05} \mathrm{O}_{12} \\
\text { synthesized by a sol-gel } \\
\text { method with citric acid }\end{array}$ & $2.5-0.0 \mathrm{~V}$ & $\begin{array}{l}\text { Initial discharge capacity is } 351.9 \\
\mathrm{mAhg}^{-1} \text { at } 35 \mathrm{mAg}^{-1} \text {; } \\
219.1 \mathrm{mAhg}^{-1} \text { after } 100 \text { cycles at } \\
350 \mathrm{mAg}^{-1} ; \\
120.2 \mathrm{mAhg}^{-1} \text { after } 100 \text { cycles at } \\
1750 \mathrm{mAg}^{-1}\end{array}$ & $\begin{array}{l}65.7 \% \text { after } 100 \\
\text { cycles at } 35 \mathrm{mAg}^{-1} ; \\
\sim 77.5 \% \text { after } 100 \\
\text { cycles at } 1750 \mathrm{mAg}^{-1}\end{array}$ \\
\hline $\begin{array}{l}\mathrm{Li}_{4} \mathrm{Ti}_{5} \mathrm{O}_{12} \text { synthesized by } \\
\text { solid-state method }\end{array}$ & $2.5-0.0 \mathrm{~V}$ & $\begin{array}{l}\text { Initial and 152th discharge } \\
\text { capacity at } 1 \mathrm{C} \text { are } 265.7 \text { and } 213 \\
\text { mAhg }^{-1} \text {, respectively }\end{array}$ & $\begin{array}{l}80 \% \text { after } 152 \text { cycles } \\
\text { at } 1 \mathrm{C}\end{array}$ \\
\hline $\mathrm{Li}_{4} \mathrm{Ti}_{4.95} \mathrm{Zr}_{0.05} \mathrm{O}_{12} / \mathrm{C}^{[\mathrm{S} 6]}$ & $2.5-0.0 \mathrm{~V}$ & $\begin{array}{l}\text { Initial discharge capacity is } \\
374.33 \mathrm{mAhg}^{-1} \text { at } 0.2 \mathrm{C} ; \\
289.03 \mathrm{mAhg}^{-1} \text { after } 50 \text { cycles at } \\
0.2 \mathrm{C} \text {; } \\
212.61 \mathrm{mAhg}^{-1} \text { at } 5 \mathrm{C}\end{array}$ & $\begin{array}{l}77.21 \% \text { after } \quad 50 \\
\text { cycles at } 0.2 \mathrm{C} \\
91.10 \% \text { after } 200 \\
\text { cycles at } 5 \mathrm{C}\end{array}$ \\
\hline $\begin{array}{l}\mathrm{Li}_{4} \mathrm{Ti}_{5} \mathrm{O}_{12} \text { synthesized by } \\
\text { solid state reaction }{ }^{[\mathrm{S} 7]}\end{array}$ & $3.0-0.0 \mathrm{~V}$ & $\sim 200 \mathrm{mAhg}^{-1}$ at $0.2 \mathrm{~mA} \mathrm{~cm}^{-2}$ & / \\
\hline $\begin{array}{l}\mathrm{Li}_{4} \mathrm{Ti}_{4.9} \mathrm{~V}_{0.1} \mathrm{O}_{12} \text { synthesized } \\
\text { by solid state reaction }\end{array}$ & $2.0-0.0 \mathrm{~V}$ & $\begin{array}{l}\text { Initial discharge capacity is } 348 \\
\mathrm{mAhg}^{-1} \text { at } 0.1 \mathrm{C} \text {; } \\
229 \mathrm{mAhg}^{-1} \text { after } 130 \text { cycles at } \\
0.1 \mathrm{C}\end{array}$ & $\begin{array}{l}65.8 \% \text { after } \\
\text { cycles at } 0.1 \mathrm{C}\end{array}$ \\
\hline $\begin{array}{l}\mathrm{Li}_{4} \mathrm{Ti}_{5} \mathrm{O}_{12} \text { synthesized by } \\
\text { solid state reaction }^{[\mathrm{S9}]}\end{array}$ & $2.0-0.01 \mathrm{~V}$ & $\begin{array}{l}213 \mathrm{mAhg}^{-1} \text { at } 0.2 \mathrm{C} \\
195 \mathrm{mAhg}^{-1} \text { at } 1 \mathrm{C} \\
181 \mathrm{mAhg}^{-1} \text { at } 5 \mathrm{C} \\
167 \mathrm{mAhg}^{-1} \text { at } 10 \mathrm{C}\end{array}$ & / \\
\hline $\begin{array}{l}\mathrm{Li}_{3.61} \mathrm{Al}_{0.13} \mathrm{Ti}_{4.9} \mathrm{O}_{11.8} \\
\text { synthesized by solid state } \\
\text { reaction }{ }^{[\mathrm{S10]}}\end{array}$ & $2.3-0.5 \mathrm{~V}$ & $\begin{array}{l}\text { Initial discharge capacity is } 199.7 \\
\mathrm{mAhg}^{-1} \text { at } 0.15 \mathrm{~mA} \mathrm{~cm}^{-2} \text {; } \\
172.8 \mathrm{mAhg}^{-1} \text { after } 40 \text { cycles at } \\
0.15 \mathrm{~mA} \mathrm{~cm}^{-2} \text {; }\end{array}$ & $\begin{array}{l}86.5 \% \text { after } 40 \text { cycles } \\
\text { at } 0.15 \mathrm{~mA} \mathrm{~cm}^{-2}\end{array}$ \\
\hline $\begin{array}{l}\mathrm{Li}_{4} \mathrm{Ti}_{4.95} \mathrm{~V}_{0.05} \mathrm{O}_{12} \text { prepared } \\
\text { by solid-state method }\end{array}$ & $2.0-0.0 \mathrm{~V}$ & $\begin{array}{l}218.4 \mathrm{mAhg}^{-1} \text { after } 50 \text { cycles at } \\
0.2 \mathrm{C}\end{array}$ & $\begin{array}{l}\sim 66 \% \text { after } 50 \text { cycles } \\
\text { at } 0.2 \mathrm{C}\end{array}$ \\
\hline $\begin{array}{l}\mathrm{Li}_{4} \mathrm{Ti}_{4.95} \mathrm{Al}_{0.05} \mathrm{O}_{12} / \mathrm{C} \\
\text { synthesized via solid state } \\
\text { reaction }\end{array}$ & $2.5-0.0 \mathrm{~V}$ & $\begin{array}{l}248 \mathrm{mAhg}^{-1} \text { after } 50 \text { cycles at } \\
0.2 \mathrm{C}\end{array}$ & $\begin{array}{l}\sim 77 \% \text { after } 50 \text { cycles } \\
\text { at } 0.2 \mathrm{C}\end{array}$ \\
\hline $\begin{array}{l}\mathrm{Li}_{4} \mathrm{Ti}_{4.95} \mathrm{Ru}_{0.05} \mathrm{O}_{12} \\
\text { synthesized via solid state } \\
\text { reaction }{ }^{[\mathrm{S} 13]}\end{array}$ & $2.5-0.01 \mathrm{~V}$ & $\begin{array}{l}222,183 \text { and } 132 \mathrm{mAhg}^{-1} \text { at } 1 \mathrm{C} \text {, } \\
5 \mathrm{C} \text { and } 10 \mathrm{C} \text {, respectively }\end{array}$ & $\begin{array}{l}95,92 \text { and } 86 \% \text { for } \\
1 \mathrm{C}, 5 \mathrm{C} \text { and } 10 \mathrm{C} \text { rates } \\
\text { over } 100 \text { cycles, } \\
\text { respectively }\end{array}$ \\
\hline $\begin{array}{l}\mathrm{Li}_{4} \mathrm{Ti}_{4.8} \mathrm{Zn}_{0.2} \mathrm{O}_{12} \quad \text { prepared } \\
\text { by solid state reaction }\end{array}$ & $2.5-0.0 \mathrm{~V}$ & $\begin{array}{l}271.6,223 \text { and } 206 \mathrm{mAhg}^{-1} \text { at } \\
0.5 \mathrm{C}, 3 \mathrm{C} \text { and } 5 \mathrm{C} \text {, respectively }\end{array}$ & $\begin{array}{l}80,89 \text { and } 90 \% \text { for } \\
0.5 \mathrm{C}, 3 \mathrm{C} \text { and } 5 \mathrm{C} \text { rates } \\
\text { over } 200 \text { cycles, } \\
\text { respectively }\end{array}$ \\
\hline
\end{tabular}



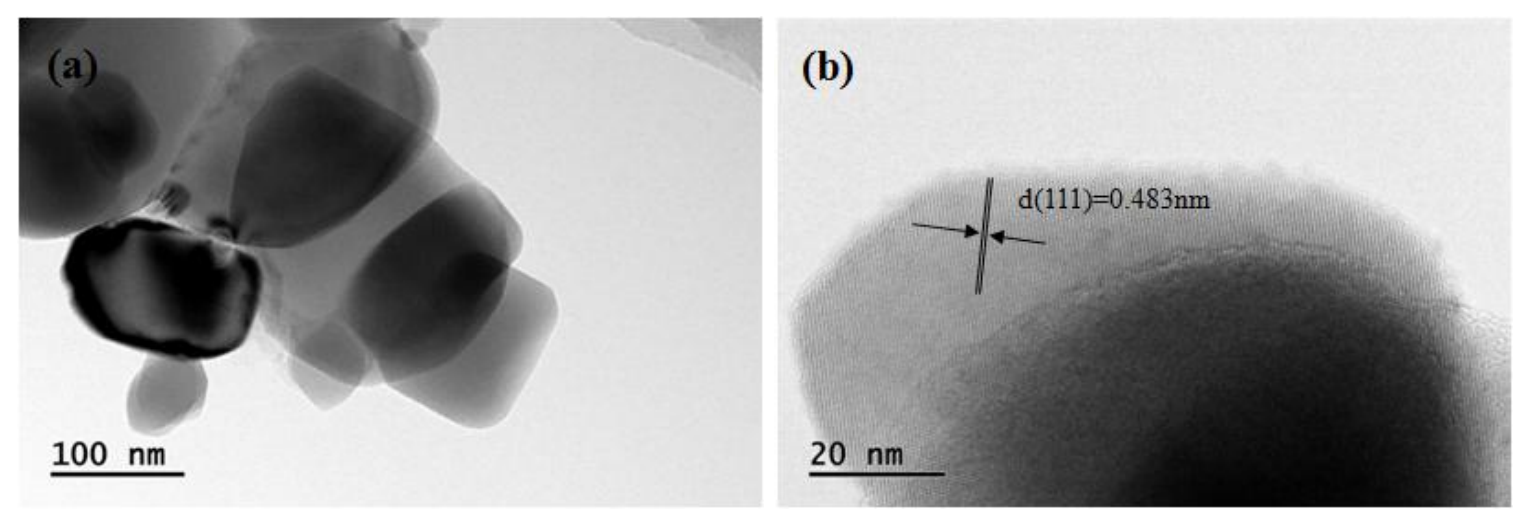

Figure S1. (a) Low magnification and (b) high resolution TEM images of as-prepared LTO particle.

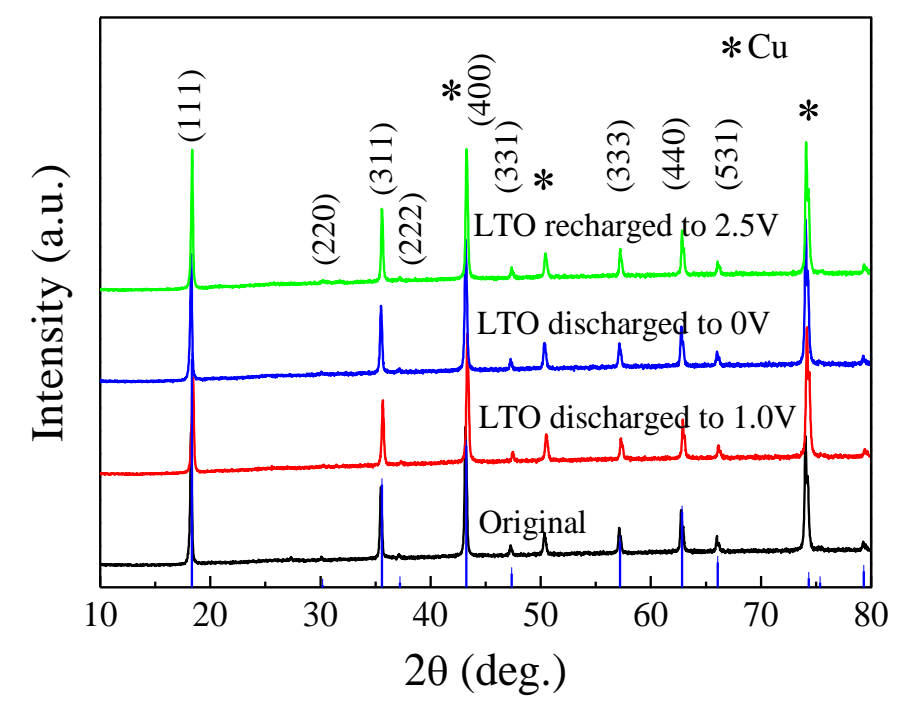

Figure S2. XRD patterns of LTO electrode during the first cycle at different discharge/charge voltages: (a) original LTO electrode; (b) LTO electrode discharged to $1 \mathrm{~V}$ in the first cycle; (c) LTO electrode discharged to $0 \mathrm{~V}$ in the first cycle; and (d) LTO electrode charged back to $2.5 \mathrm{~V}$ in the first cycle. 
(a)

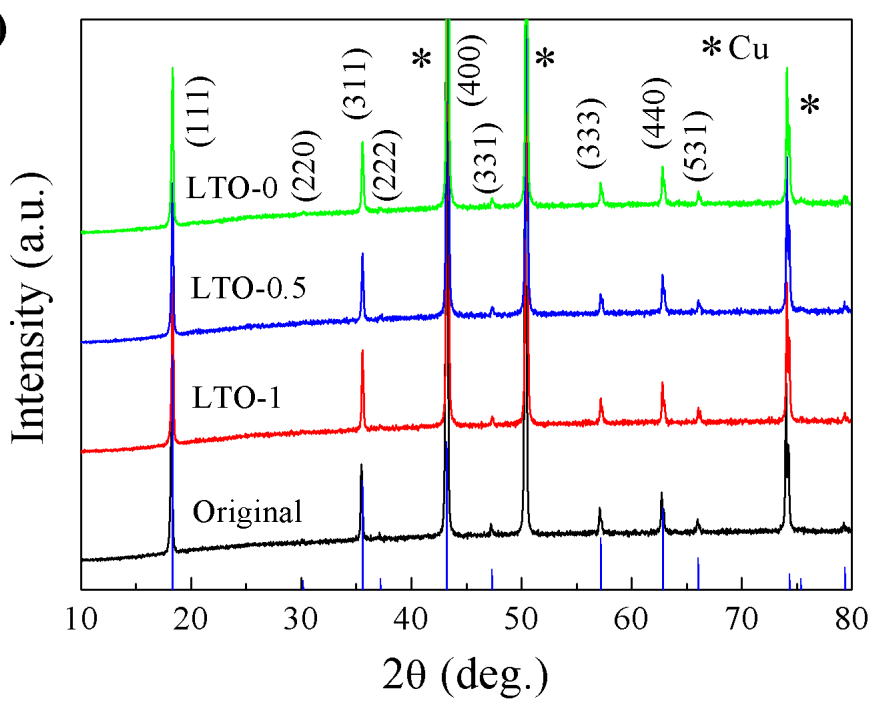

(b)

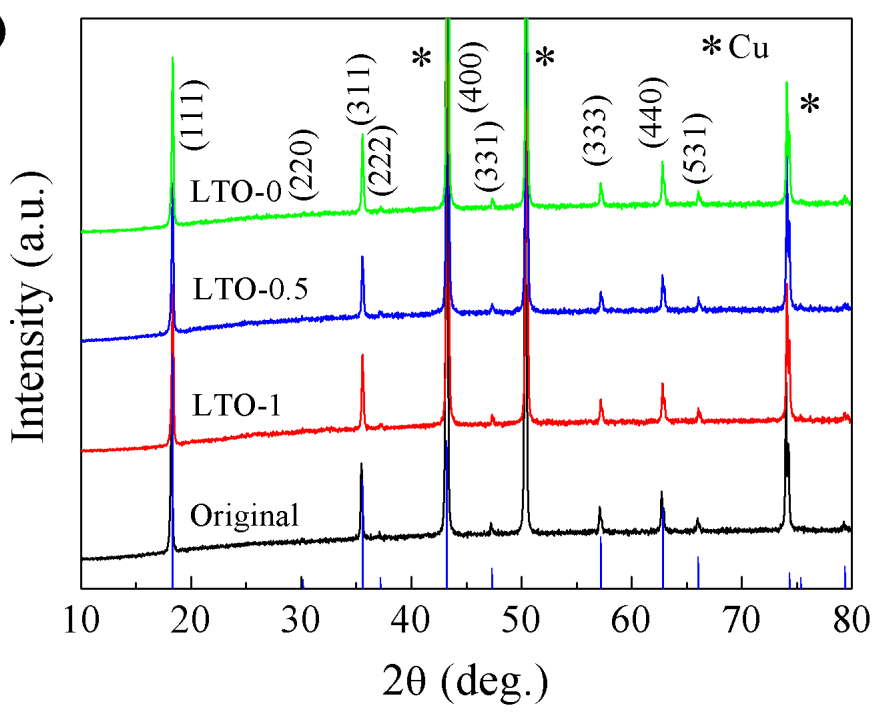

Figure S3. XRD patterns of the LTO electrode over different voltage range after (a) 3 cycles at $0.1 \mathrm{C}$ and (b) rate capability test. 

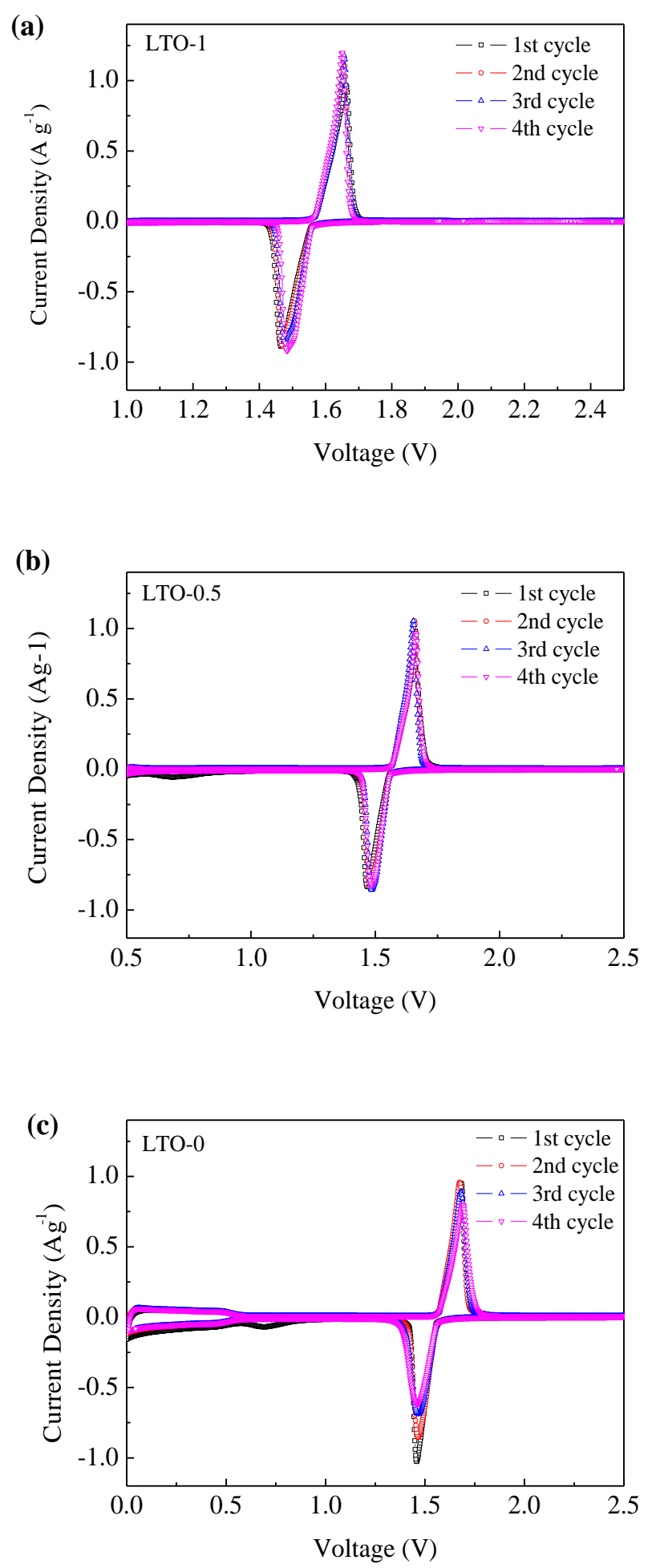

Figure S4. CV profiles of (a) LTO-1, (b) LTO-0.5 and (c) LTO-0 at scan rate of $0.1 \mathrm{mVs}^{-1}$ 
(a)

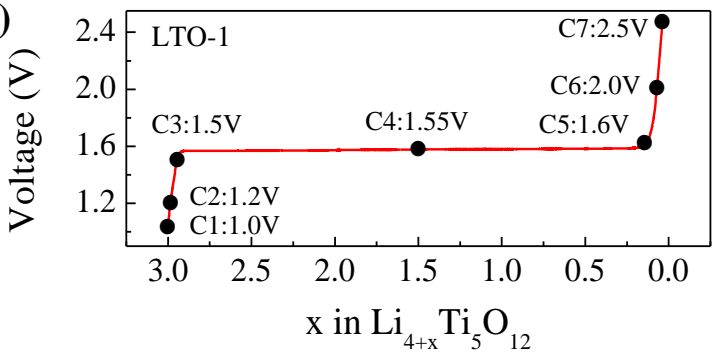

(c)

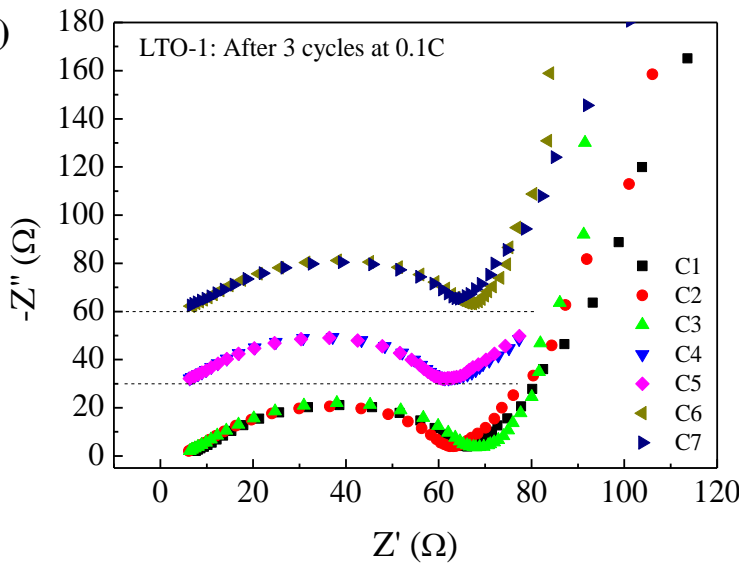

(e)

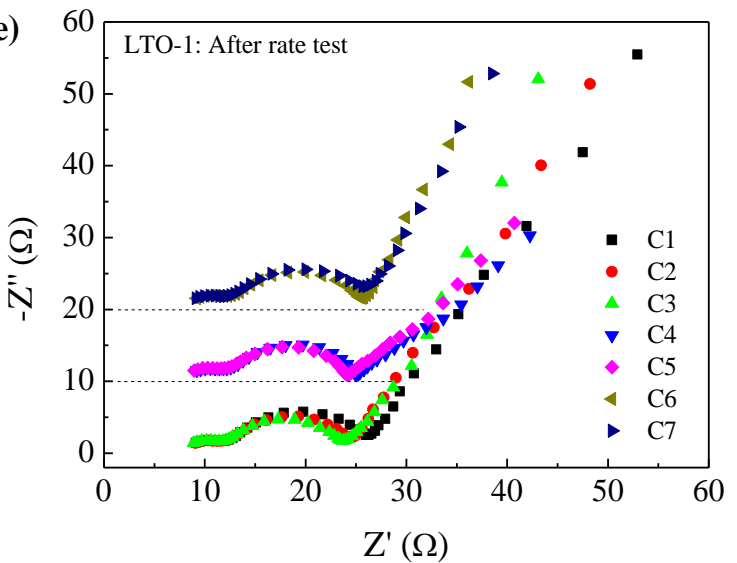

(g)

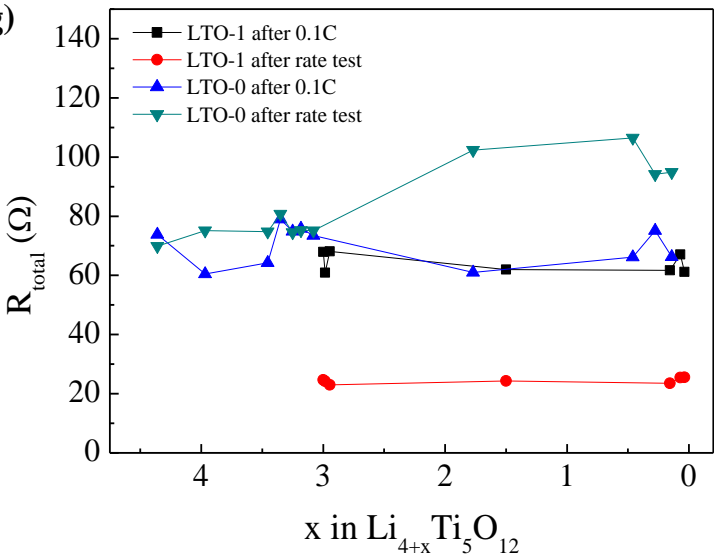

(b)

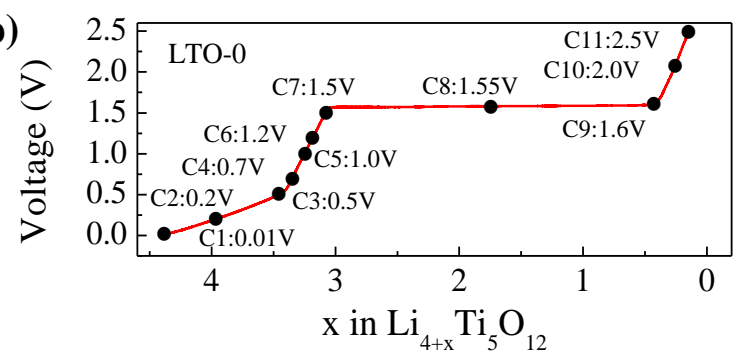

(d)

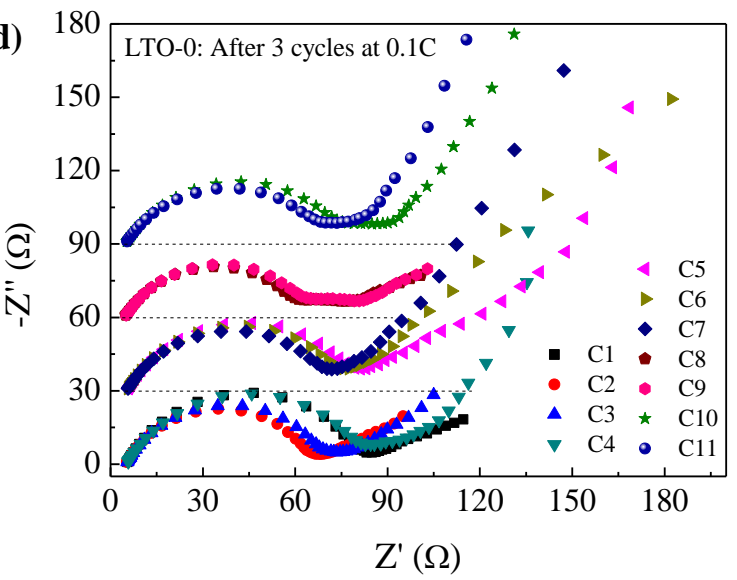

(f)

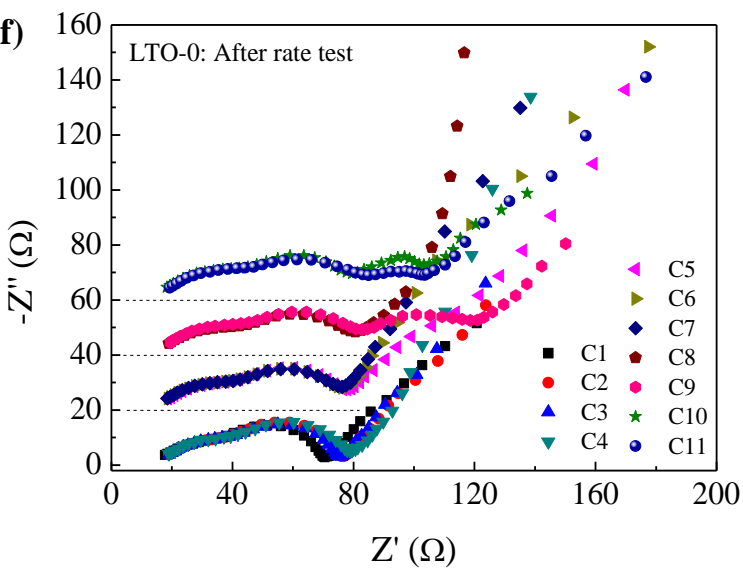

(h)

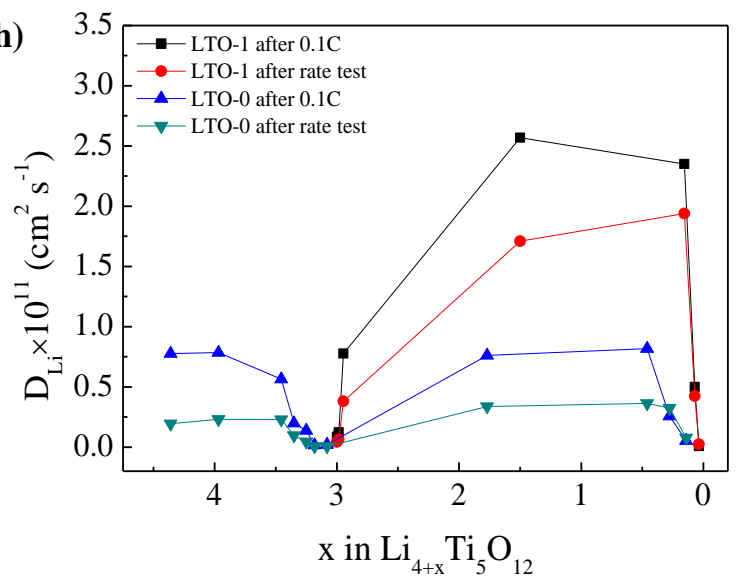

Figure S5 Selected points for EIS measurements during the charge process of (a) LTO-1 and 
(b) LTO-0 electrode at 0.1C current rate. Measured EIS of (c, e) LTO-1 and (d, f) LTO-0 electrodes during the charge process $(c, d)$ after 3 cycles at $0.1 \mathrm{C}$, and $(e, f)$ after the rate capability test. (g) Simulated total cell impedence, $R_{\text {total }}$ and (h) calculated lithium ion diffusion coefficient, $D_{L i}$ of LTO-1 and LTO-0 during the charge process after 3 cycles at $0.1 \mathrm{C}$ and after the rate capability test. 
(a)

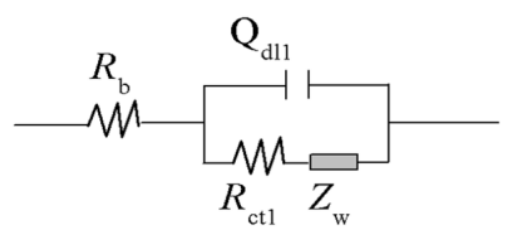

(b)

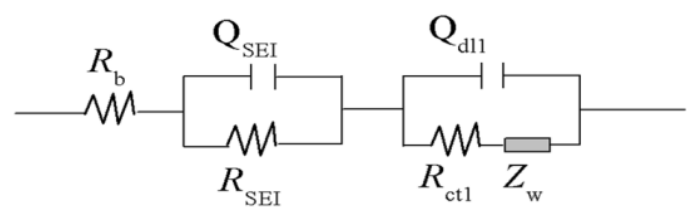

(c)

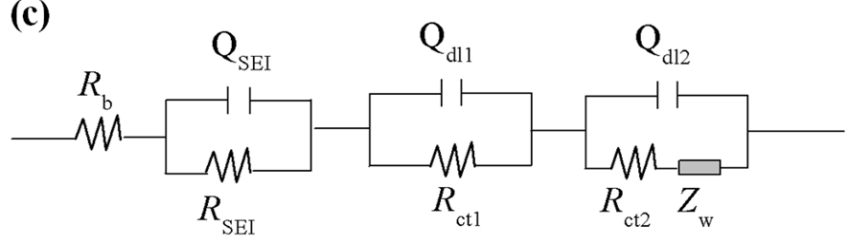

Figure S6. Equivalent circuit models used for the EIS simulation: (a) for EIS spectra with one semicircle and one sloping line, where $R_{\mathrm{b}}$ is the ohmic resistance. The semicircle is related to the charge-transfer through the electrode/electrolyte interface, and the Warburg-type element $Z_{\mathrm{w}}$ is used to represent the lithium ion diffusion in the low-frequency region; (b) for EIS spectra with two semicircles and one sloping line. The semicircle at high frequency is related to the lithium ion migration through the SEI film covering electrode surface, the middle frequency semicircle is related to the charge-transfer through the electrode/electrolyte interface; (c) for EIS spectra with three semicircles and one sloping line. The semicircle at high frequency is related to the lithium ion migration through the SEI film covering electrode surface, the middle-to-high frequency semicircle (MHFS) is related to the charge-transfer through the electrode/electrolyte interface. The origin of the middle-to-low frequency semicircle (MLFS) is not clear and may be related to the charge-transfer process. 
Table S2. Simulation results of EIS spectra in Figure 5c, 5d, 5e and 5f, and the corresponding calculated $D_{L i}$ during the discharge process

\begin{tabular}{|c|c|c|c|c|c|c|c|c|c|}
\hline Sample & Test & $\begin{array}{l}\text { Voltage } \\
\text { [V] }\end{array}$ & $\begin{array}{l}x \text { in } \\
\mathrm{Li}_{4+x} \mathrm{Ti}_{5} \mathrm{O}_{12}\end{array}$ & $R_{\mathrm{b}}[\Omega]$ & $\boldsymbol{R}_{\mathrm{SEI}}[\Omega]$ & $\boldsymbol{R}_{\mathrm{ct} 1}[\Omega]$ & $\boldsymbol{R}_{\mathrm{ct} 2}[\Omega]$ & $R_{\text {total }}[\Omega]$ & $\begin{array}{l}D_{L i} \\
{\left[\mathbf{c m}^{2} \mathbf{s}^{-}\right.} \\
\mathbf{1}_{]}\end{array}$ \\
\hline \multirow{7}{*}{ LTO-1 } & \multirow{7}{*}{$\begin{array}{l}\text { After } \\
3 \\
\text { cycles } \\
\text { at } \\
0.1 \mathrm{C}\end{array}$} & 2.3 & 0 & 5.8 & I & 61.6 & I & 67.4 & $5.2 \mathrm{E}-15$ \\
\hline & & 2.0 & 0.0034 & 5.9 & / & 66.2 & I & 72.1 & $4.5 \mathrm{E}-15$ \\
\hline & & 1.6 & 0.065 & 6.1 & / & 63.8 & I & 69.9 & $2.1 \mathrm{E}-11$ \\
\hline & & 1.55 & 1.50 & 6.2 & I & 62.3 & I & 68.5 & $2.4 \mathrm{E}-11$ \\
\hline & & 1.5 & 2.88 & 7.2 & I & 62.0 & I & 69.2 & $3.2 \mathrm{E}-11$ \\
\hline & & 1.2 & 2.93 & 7.4 & / & 64.6 & I & 72.0 & $5.3 \mathrm{E}-12$ \\
\hline & & 1.0 & 3.00 & 7.3 & I & 60.7 & I & 68.0 & $8.6 \mathrm{E}-13$ \\
\hline \multirow{6}{*}{ LTO-1 } & \multirow{6}{*}{$\begin{array}{l}\text { After } \\
\text { rate } \\
\text { test }\end{array}$} & 2.0 & 0 & 6.8 & 6.3 & 11.2 & I & 24.3 & $1.9 \mathrm{E}-12$ \\
\hline & & 1.6 & 0.0034 & 6.7 & 6.9 & 10.5 & I & 24.1 & $1.3 \mathrm{E}-11$ \\
\hline & & 1.55 & 1.50 & 6.6 & 6.4 & 10.4 & I & 23.4 & $1.4 \mathrm{E}-11$ \\
\hline & & 1.5 & 2.88 & 7.0 & 6.2 & 12.2 & I & 25.4 & $1.4 \mathrm{E}-11$ \\
\hline & & 1.2 & 2.93 & 6.8 & 5.9 & 11.1 & I & 23.8 & $2.4 \mathrm{E}-12$ \\
\hline & & 1.0 & 3.00 & 7.0 & 6.5 & 12.2 & I & 25.7 & $4.3 \mathrm{E}-13$ \\
\hline \multirow{10}{*}{ LTO-0 } & \multirow{10}{*}{$\begin{array}{l}\text { after } \\
3 \\
\text { cycles } \\
\text { at } \\
0.1 \mathrm{C}\end{array}$} & 2.0 & 0 & 5.3 & / & 64.2 & I & 69.5 & $8.4 \mathrm{E}-13$ \\
\hline & & 1.6 & 0.094 & 5.0 & I & 61.4 & I & 66.4 & $1.0 \mathrm{E}-11$ \\
\hline & & 1.55 & 1.25 & 4.2 & / & 58.5 & 7.8 & 70.5 & $9.2 \mathrm{E}-12$ \\
\hline & & 1.5 & 2.60 & 4.2 & I & 57.6 & 8.7 & 70.5 & $6.9 \mathrm{E}-12$ \\
\hline & & 1.2 & 2.73 & 4.9 & I & 58.5 & 9.5 & 72.9 & $5.5 \mathrm{E}-12$ \\
\hline & & 1.0 & 2.81 & 4.5 & I & 57.9 & I & 62.4 & $1.5 \mathrm{E}-13$ \\
\hline & & 0.7 & 2.95 & 4.8 & / & 50.6 & / & 55.4 & $1.2 \mathrm{E}-12$ \\
\hline & & 0.5 & 3.11 & 4.7 & / & 64.1 & I & 68.8 & $3.2 \mathrm{E}-12$ \\
\hline & & 0.2 & 3.73 & 3.9 & / & 58.3 & I & 62.2 & $9.0 \mathrm{E}-12$ \\
\hline & & 0.01 & 4.36 & 4.3 & I & 69.5 & I & 73.8 & $7.8 \mathrm{E}-12$ \\
\hline \multirow{9}{*}{ LTO-0 } & \multirow{9}{*}{$\begin{array}{l}\text { after } \\
\text { rate } \\
\text { test }\end{array}$} & 1.6 & 0 & 13.9 & 26.8 & 38.9 & 25.7 & 105.3 & $1.5 \mathrm{E}-12$ \\
\hline & & 1.55 & 1.25 & 13.4 & 22.8 & 30.6 & 38.9 & 105.7 & $1.1 \mathrm{E}-12$ \\
\hline & & 1.5 & 2.60 & 13.5 & 23.3 & 31.7 & 42.9 & 111.4 & $1.3 \mathrm{E}-12$ \\
\hline & & 1.2 & 2.73 & 13.5 & 22.5 & 32.4 & 42.4 & 110.8 & $1.2 \mathrm{E}-12$ \\
\hline & & 1.0 & 2.81 & 13.7 & 20.6 & 34.3 & 27.0 & 95.6 & 7.9E-12 \\
\hline & & 0.7 & 2.95 & 14.2 & 27.8 & 35.4 & I & 77.4 & $3.4 \mathrm{E}-14$ \\
\hline & & 0.5 & 3.11 & 13.6 & 22.5 & 36.1 & I & 72.2 & $5.9 \mathrm{E}-13$ \\
\hline & & 0.2 & 3.73 & 13.8 & 24.9 & 36.8 & I & 75.5 & $2.1 \mathrm{E}-12$ \\
\hline & & 0.01 & 4.36 & 13.7 & 22.4 & 33.8 & I & 69.9 & $1.9 \mathrm{E}-12$ \\
\hline
\end{tabular}


Table S3. Simulation results of EIS spectra in Figure S3c, S3d, S3e and S3f, and the corresponding calculated $D_{\mathrm{Li}}$ values during the charge process

\begin{tabular}{|c|c|c|c|c|c|c|c|c|c|}
\hline Sample & Test & $\begin{array}{l}\text { Voltage } \\
{[\text { V] }}\end{array}$ & $\begin{array}{l}x \text { in } \\
\mathrm{Li}_{4+x} \mathrm{Ti}_{5} \mathrm{O}_{12}\end{array}$ & $R_{\mathrm{b}}[\Omega]$ & $\boldsymbol{R}_{\mathrm{SEI}}[\mathbf{\Omega}]$ & $\boldsymbol{R}_{\mathrm{ct} 1}[\mathbf{\Omega}]$ & $\boldsymbol{R}_{\mathrm{ct} 2}[\mathbf{\Omega}]$ & $\boldsymbol{R}_{\text {total }}[\Omega]$ & $\begin{array}{l}D_{\mathrm{Li}} \\
{\left[\mathrm{cm}^{2}\right.} \\
\left.{ }_{1}^{1}\right]\end{array}$ \\
\hline \multirow{7}{*}{ LTO-1 } & \multirow{7}{*}{$\begin{array}{l}\text { After } \\
3 \\
\text { cycles } \\
\text { at } \\
0.1 \mathrm{C}\end{array}$} & 1.0 & 3.00 & 7.3 & I & 60.7 & \multirow[t]{7}{*}{ I } & 68.0 & $8.6 \mathrm{E}-13$ \\
\hline & & 1.2 & 2.98 & 6.1 & I & 54.8 & & 60.9 & $1.2 \mathrm{E}-12$ \\
\hline & & 1.5 & 2.95 & 6.1 & / & 62.1 & & 68.2 & $7.8 \mathrm{E}-12$ \\
\hline & & 1.55 & 1.50 & 5.7 & I & 56.3 & & 62.0 & $2.6 \mathrm{E}-11$ \\
\hline & & 1.6 & 0.16 & 5.7 & I & 55.9 & & 61.6 & $2.4 \mathrm{E}-11$ \\
\hline & & 2.0 & 0.07 & 6.0 & I & 61.0 & & 67.0 & $5.0 \mathrm{E}-12$ \\
\hline & & 2.5 & 0.04 & 6.4 & I & 54.8 & & 61.2 & 7.4E-14 \\
\hline \multirow{7}{*}{ LTO-1 } & \multirow{7}{*}{$\begin{array}{l}\text { After } \\
\text { rate } \\
\text { test }\end{array}$} & 1.0 & 3.00 & 7.4 & 6.2 & 11.0 & I & 24.6 & $4.3 \mathrm{E}-13$ \\
\hline & & 1.2 & 2.98 & 7.1 & 6.0 & 11.1 & I & 24.2 & $6.2 \mathrm{E}-13$ \\
\hline & & 1.5 & 2.95 & 7.1 & 5.5 & 10.5 & I & 23.1 & $3.8 \mathrm{E}-12$ \\
\hline & & 1.55 & 1.50 & 6.7 & 7.1 & 10.5 & l & 24.3 & $1.7 \mathrm{E}-11$ \\
\hline & & 1.6 & 0.16 & 6.7 & 6.8 & 10.0 & I & 23.5 & $1.9 \mathrm{E}-11$ \\
\hline & & 2.0 & 0.07 & 7.0 & 6.5 & 11.9 & & 25.4 & 4.2E-12 \\
\hline & & 2.5 & 0.04 & 7.1 & 6.1 & 12.4 & I & 25.6 & $2.4 \mathrm{E}-13$ \\
\hline \multirow{11}{*}{ LTO-0 } & \multirow{11}{*}{$\begin{array}{l}\text { after } \\
3 \\
\text { cycles } \\
\text { at } \\
0.1 \mathrm{C}\end{array}$} & 0.01 & 4.36 & 4.3 & I & 69.5 & I & 73.8 & $7.8 \mathrm{E}-12$ \\
\hline & & 0.2 & 3.97 & 3.8 & I & 56.6 & l & 60.4 & $7.8 \mathrm{E}-12$ \\
\hline & & 0.5 & 3.46 & 4.4 & I & 59.8 & l & 64.2 & $5.6 \mathrm{E}-12$ \\
\hline & & 0.7 & 3.35 & 5.3 & I & 73.7 & I & 79.0 & $2.0 \mathrm{E}-12$ \\
\hline & & 1.0 & 3.25 & 5.4 & / & 69.4 & / & 74.8 & $1.4 \mathrm{E}-12$ \\
\hline & & 1.2 & 3.18 & 5.5 & I & 70.4 & l & 75.9 & $1.6 \mathrm{E}-13$ \\
\hline & & 1.5 & 3.08 & 5.4 & I & 68.0 & / & 73.4 & $2.1 \mathrm{E}-13$ \\
\hline & & 1.55 & 1.77 & 3.8 & I & 52.2 & 5.0 & 61.0 & $7.6 \mathrm{E}-12$ \\
\hline & & 1.6 & 0.46 & 3.8 & I & 55.4 & 6.9 & 66.1 & $8.2 \mathrm{E}-12$ \\
\hline & & 2.0 & 0.28 & 4.9 & I & 70.3 & I & 75.2 & $2.6 \mathrm{E}-12$ \\
\hline & & 2.5 & 0.14 & 4.9 & I & 61.4 & I & 66.3 & $5.3 \mathrm{E}-13$ \\
\hline \multirow{11}{*}{ LTO-0 } & \multirow{11}{*}{$\begin{array}{l}\text { after } \\
\text { rate } \\
\text { test }\end{array}$} & 0.01 & 4.36 & 13.7 & 22.4 & 33.8 & I & 69.9 & $1.9 \mathrm{E}-12$ \\
\hline & & 0.2 & 3.97 & 15.3 & 26.6 & 33.3 & l & 75.2 & $2.3 \mathrm{E}-12$ \\
\hline & & 0.5 & 3.46 & 15.2 & 25.6 & 33.9 & l & 74.7 & $2.3 \mathrm{E}-12$ \\
\hline & & 0.7 & 3.35 & 13.5 & 22.7 & 44.6 & I & 80.8 & $9.6 \mathrm{E}-13$ \\
\hline & & 1.0 & 3.25 & 14.2 & 22.0 & 38.3 & I & 74.5 & $4.5 \mathrm{E}-13$ \\
\hline & & 1.2 & 3.18 & 14.3 & 23.2 & 37.7 & I & 75.2 & $5.6 \mathrm{E}-14$ \\
\hline & & 1.5 & 3.08 & 14.1 & 23.9 & 37.0 & I & 75.0 & $5.3 \mathrm{E}-14$ \\
\hline & & 1.55 & 1.77 & 14.2 & 24.2 & 37.9 & 26.0 & 102.3 & $3.4 \mathrm{E}-12$ \\
\hline & & 1.6 & 0.46 & 14.4 & 25.0 & 39.0 & 28.1 & 106.5 & $3.6 \mathrm{E}-12$ \\
\hline & & 2.0 & 0.28 & 13.9 & 22.5 & 39.9 & 17.9 & 94.2 & $3.2 \mathrm{E}-12$ \\
\hline & & 2.5 & 0.14 & 14.4 & 23.5 & 43 & 14.0 & 94.9 & 7.7E-13 \\
\hline
\end{tabular}



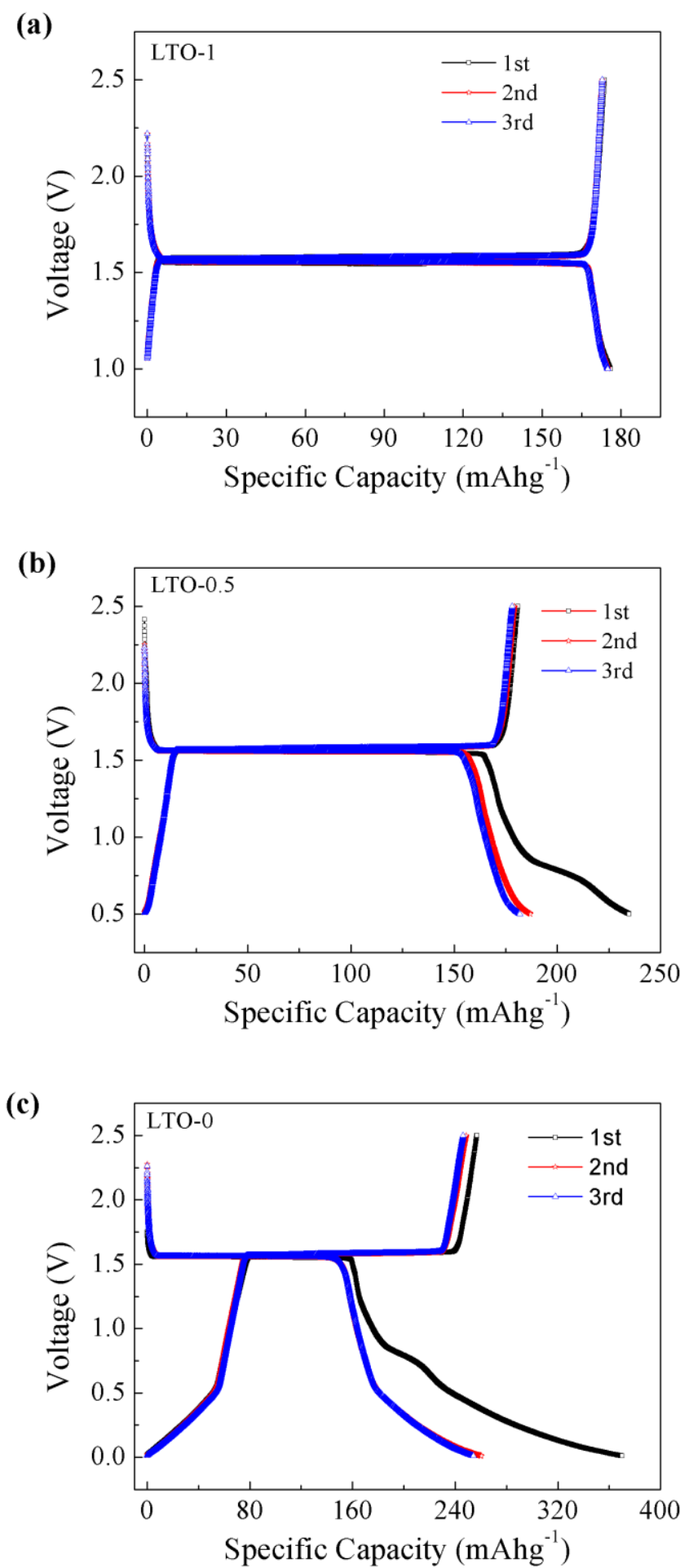

Figure S7. Initial three charge/discharge curves of (a) LTO-1, (b) LTO-0.5, and (c) LTO-0 electrodes at $0.1 \mathrm{C}$. 
(a)

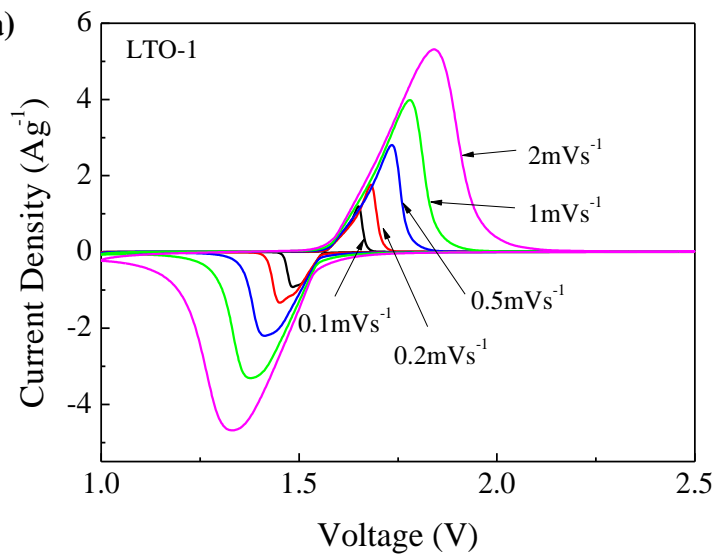

(c)

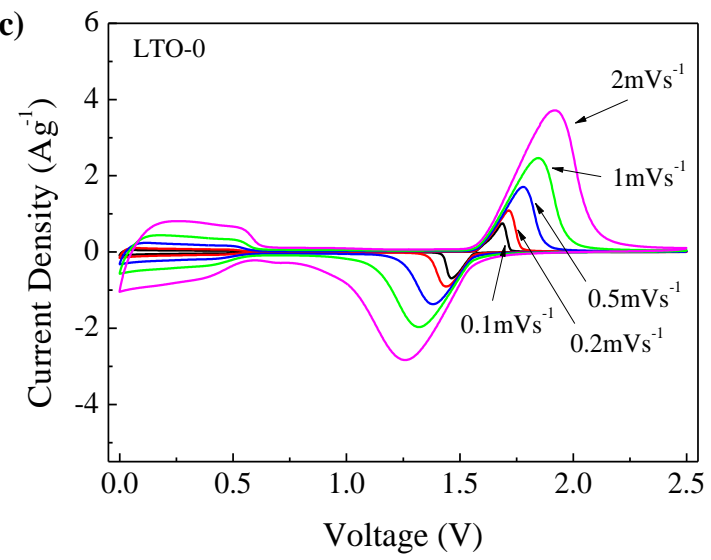

(b)

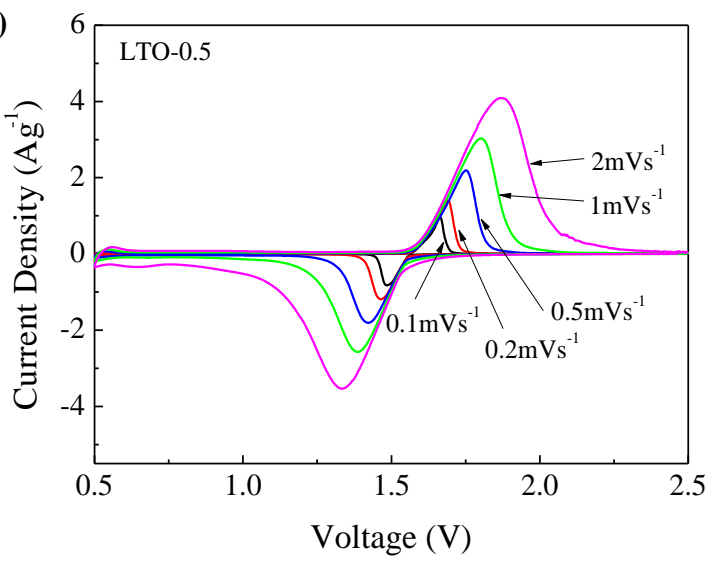

(d)

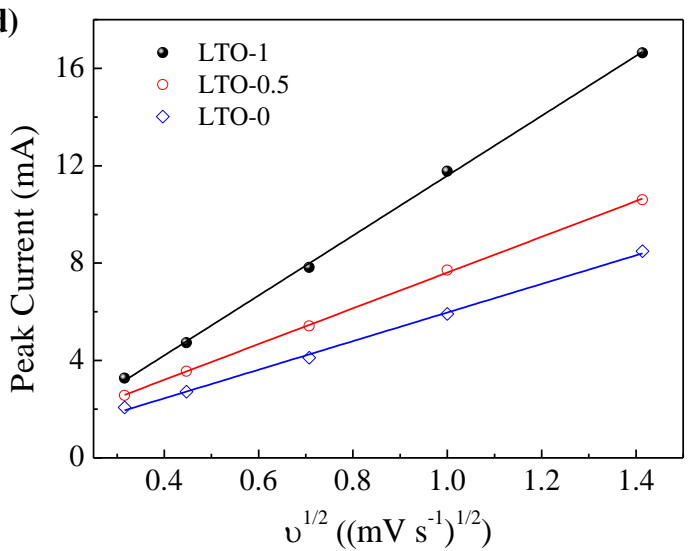

Figure S8. CV characteristics of (a) LTO-1, (b) LTO-0.5 and (c) LTO-0 electrodes at different scanning rates ranging from $0.1 \mathrm{mVs}^{-1}$ to $2 \mathrm{mVs}^{-1}$; (d) anodic peak current plotted $v s$. the square root of the scanning rate.

The CV curves of LTO-1, LTO-0.5 and LTO-0 electrodes at different scanning rates were measured using the same cells. The linear relations of the anodic peak currents $v s$. the square root of the scanning rate shown in Figure S6d suggested an obvious diffusioncontrolled reaction according to the Randles-Sevcik equation (equation S1): ${ }^{[S 15, S 16]}$

$$
I_{\mathrm{p}}=\left(2.69 \times 10^{-5}\right) n^{3 / 2} A D^{1 / 2} C v^{1 / 2}
$$

Where $n$ is the number of transferred electrons, $A$ is the surface area of the electrode, $D$ is the diffusion coefficient, and $C$ is the concentration of reactants. 
The slopes of the fitted lines $\left(I_{\mathrm{p}}\right.$ vs. $\left.v^{1 / 2}\right)$ represented the Li-ion diffusion coefficients $(D)$ (Figure S6d). The $D$ for LTO electrode cycling from $1.0 \mathrm{~V}$ to $2.5 \mathrm{~V}$ (i.e., sample LTO-1) was $1.27 \times 10^{-10} \mathrm{~cm}^{2} \mathrm{~s}^{-1}$, which is 2.8 times and 4.4 times the LTO cycled down to $0.5 \mathrm{~V}(D=$ $4.51 \times 10^{-11} \mathrm{~cm}^{2} \mathrm{~s}^{-1}$; sample LTO-0.5) and $0 \mathrm{~V}\left(2.89 \times 10^{-11} \mathrm{~cm}^{2} \mathrm{~s}^{-1}\right.$; sample LTO-0), respectively. This results matched very well with the EIS measurement in Figure 5 and S3. 


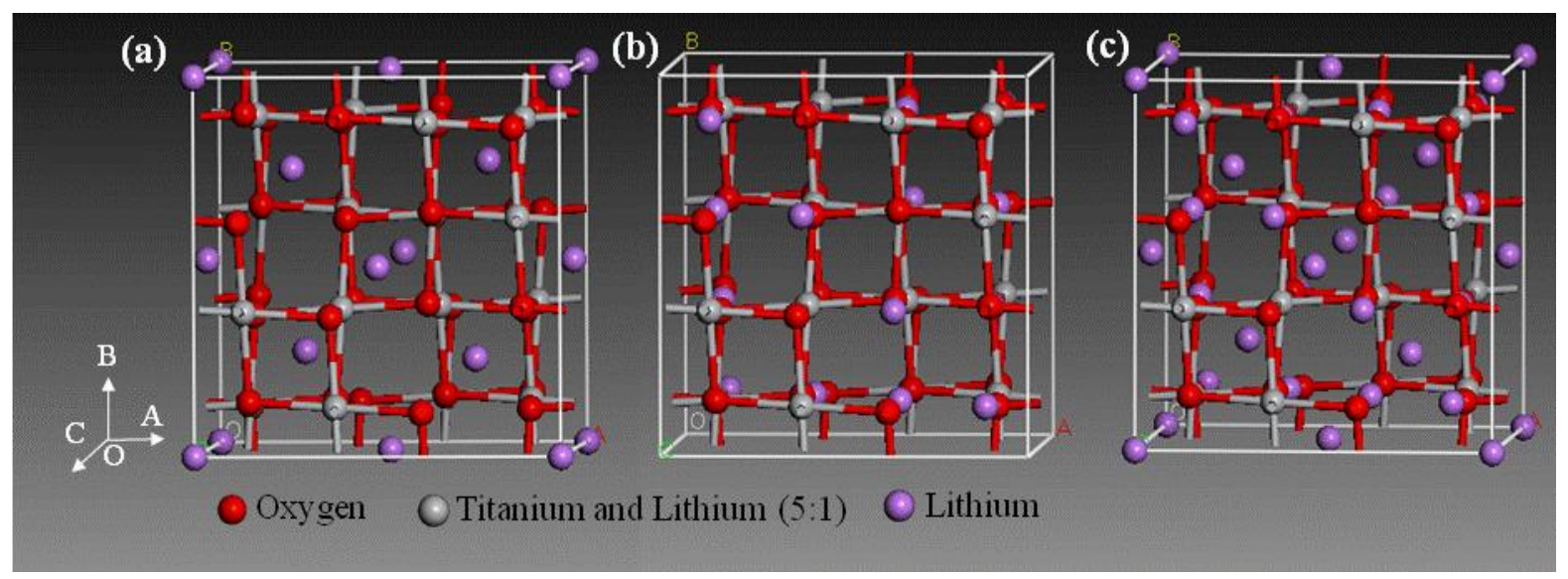

Figure S9. Crystal structures of (a) $\mathrm{Li}_{4} \mathrm{Ti}_{5} \mathrm{O}_{12}$, (b) $\mathrm{Li}_{7} \mathrm{Ti}_{5} \mathrm{O}_{12}$, (c) $\mathrm{Li}_{10} \mathrm{Ti}_{5} \mathrm{O}_{12}$, in which the red ball represents the oxygen atoms at 32e sites, the grey ball represents the titanium and oxygen atoms (in a molar ration of 5:1) at $16 \mathrm{~d}$ sites, while the purple ball represents the lithium atoms. (a) The structure of spinel $\mathrm{Li}_{4} \mathrm{Ti}_{5} \mathrm{O}_{12}$ belongs to $\mathrm{Fd} 3 \mathrm{~m}$ space group, in which the oxygen atoms take $32 \mathrm{e}$ sites, all the titanium atoms and 1/4 lithium atoms take $16 \mathrm{~d}$ sites (molar ration of $\mathrm{Ti}: \mathrm{Li}=5: 1$ ), and 3/4 lithium atoms take $8 \mathrm{a}$ tetrahedral sites. (b) In the case of $\mathrm{Li}_{7} \mathrm{Ti}_{5} \mathrm{O}_{12}$, the intercalated 3 mol lithium atoms take 16c sites. At the same time, lithium atoms initially located at $8 \mathrm{a}$ sites also transport to $16 \mathrm{c}$ sites, leaving behind the empty $8 \mathrm{a}$ sites. (c) Further intercalated lithium ions take the empty 8 a sites. 
(a)

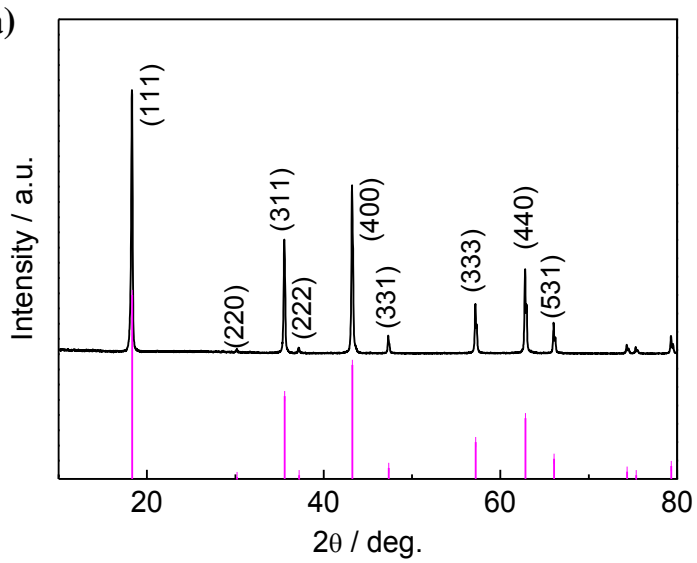

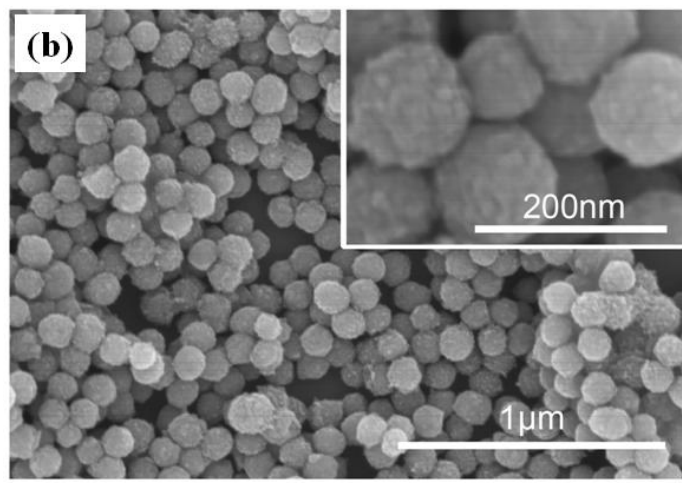

(c)

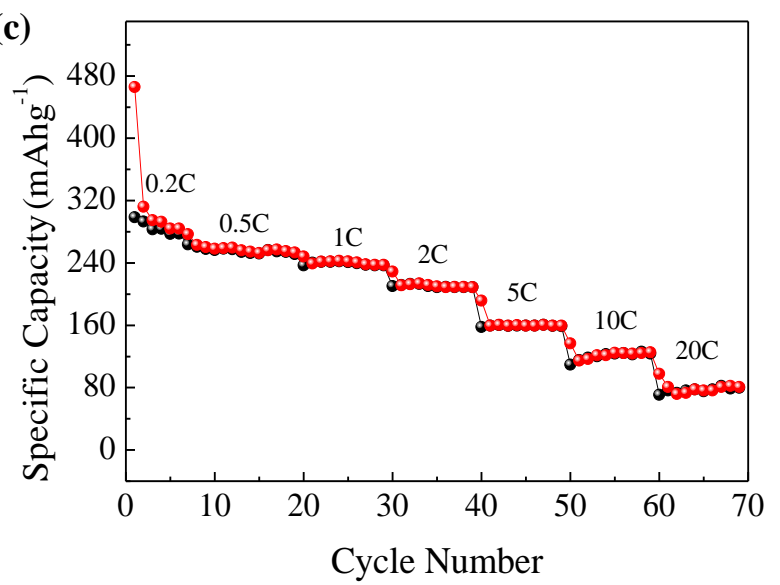

Figure S10. (a) XRD pattern and (b) SEM image of LTO nanosphere prepared via the use of titanium nitride $(\mathrm{TiN})$ as a titanium source. ${ }^{[\mathrm{S} 17]}$ (c) Rate performance of as-prepared LTO nanosphere electrode.

The densely packed phase-pure LTO nanosphere with an average diameter of $120 \mathrm{~nm}$ were prepared according to Ref S17 (Figure S10a). The monodisperse LTO nanospheres composed of interconnected LTO nanograins with an average size of only $15 \mathrm{~nm}$ (Figure S10b). When discharged down to 0V, the LTO nanosphere delivered a stable specific capacity of $121.4 \mathrm{mAhg}^{-1}$ and $77.6 \mathrm{mAhg}^{-1}$ at $10 \mathrm{C}$ and $20 \mathrm{C}$, respectively, indicating that the large polarization of LTO within the extended voltage range can be reduced via proper structural design and morphological control (Figure S10c). 

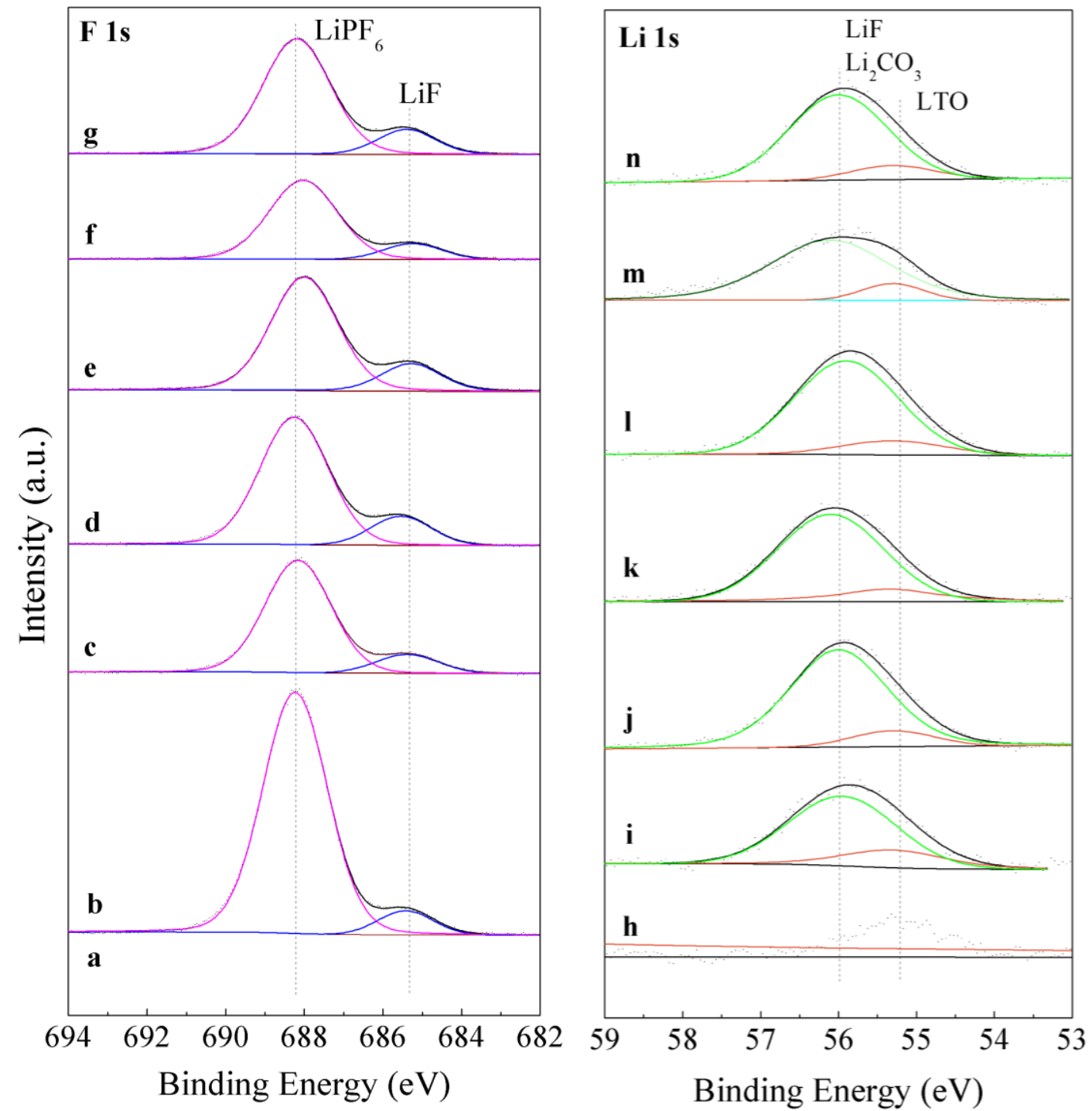

Figure S11. Detailed XPS spectra of F1s and Li1s of LTO electrode under different conditions: (a, h) as-prepared LTO powder, (b, i) LTO-1, (c, j) LTO-0.5, and (d, k) LTO-0 electrodes after 3 cycles at $0.1 \mathrm{C}$; (e, l) LTO-1, (f, m) LTO-0.5, and (g, n) LTO-0 electrodes after rate capability test. 
Table S4. Elemental composition of LTO electrode surface at various stages determined by XPS analysis

\begin{tabular}{llllllll}
\hline \multirow{2}{*}{ Electrode } & Test & Voltage & Ti2p & O1s & C1s & Li1s & F1s \\
& & Range & {$[\%]$} & {$[\%]$} & {$[\%]$} & {$[\%]$} & {$[\%]$} \\
\hline Original LTO & & $/$ & 9.0 & 59.0 & 23.9 & 8.1 & $/$ \\
LTO-1 & After 3 cycles at 0.1C & $2.5-1.0 \mathrm{~V}$ & 4.2 & 27.4 & 41.8 & 12.0 & 14.6 \\
LTO-0.5 & After 3 cycles at 0.1C & $2.5-0.5 \mathrm{~V}$ & 1.9 & 34.2 & 37.1 & 18.1 & 8.8 \\
LTO-0 & After 3 cycles at $0.1 \mathrm{C}$ & $2.5-0 \mathrm{~V}$ & 2.2 & 31.3 & 40.4 & 15.9 & 10.1 \\
LTO-1 & After rate test & $2.5-1.0 \mathrm{~V}$ & 1.7 & 34.2 & 37.8 & 16.7 & 9.6 \\
LTO-0.5 & After rate test & $2.5-0.5 \mathrm{~V}$ & 1.5 & 34.8 & 40.1 & 16.0 & 7.6 \\
LTO-0 & After rate test & $2.5-0 \mathrm{~V}$ & 1.4 & 32.2 & 41.0 & 15.2 & 10.3 \\
& & & & & & & \\
\hline
\end{tabular}


(a)

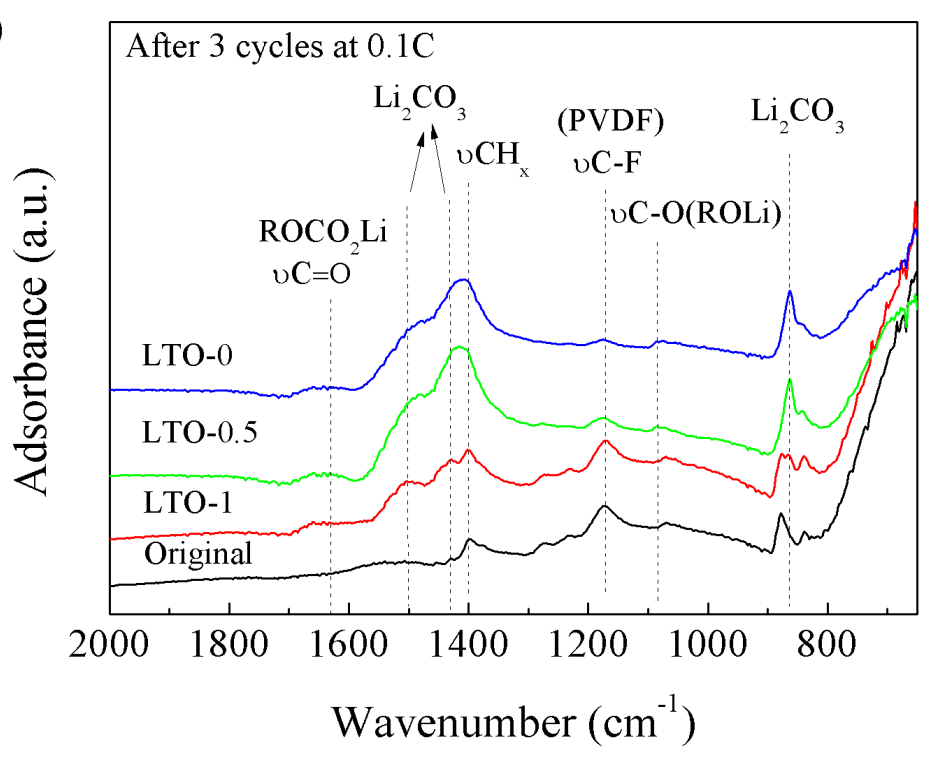

(b)

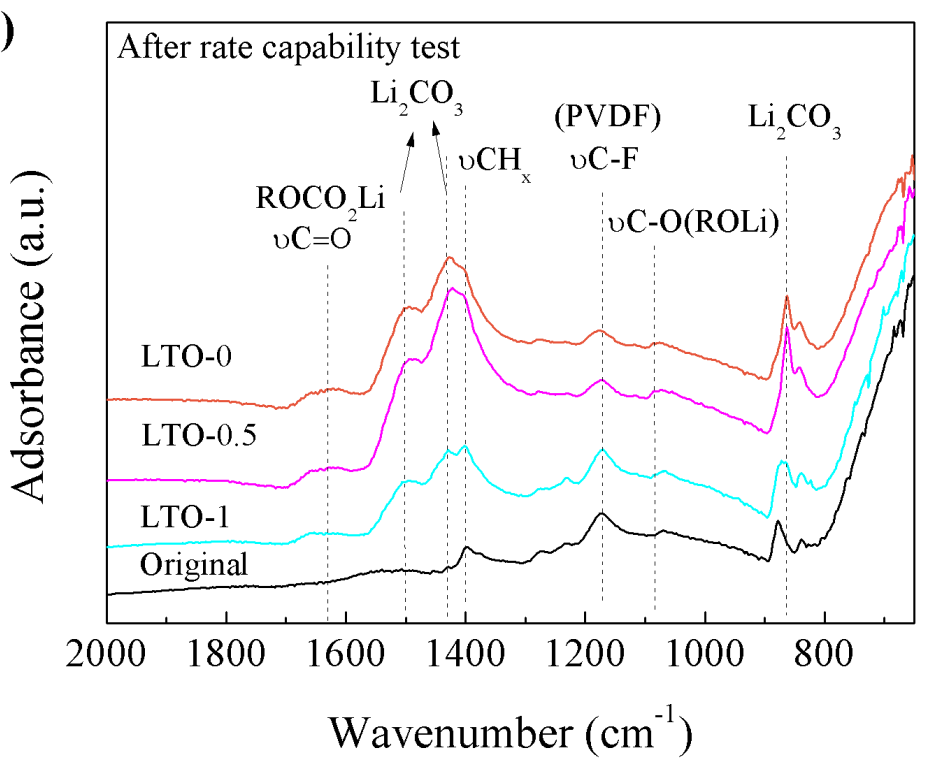

Figure S12. FTIR spectra of original LTO and LTO-1, LTO-0.5, LTO-0 electrodes (a) after 3 cycles at $0.1 \mathrm{C}$, and (b) after rate capability test. 


\section{References:}

[S1] Wang Y.; Zou W.; Huang Z.; Li J. $\mathrm{Al}_{2} \mathrm{O}_{3}$ Coated $\mathrm{Li}_{4} \mathrm{Ti}_{5} \mathrm{O}_{12}$ Electrode with Enhanced Cycle Performance for Lithium Ion Battery, Ecs Transactions 2014, 59, 35-43.

[S2] Zhou T.; LinY.; Zhao G.; Huang Y.; Lai H.; Li J.; Huang Z.; Wu S. The Enhancement Role of $\mathrm{ZnO}$ Surface Modification on Electrochemical Performance of $\mathrm{Li}_{4} \mathrm{Ti}_{5} \mathrm{O}_{12} / \mathrm{ZnO}$ Composites, Int. J. Electrochem. Sci. 2013, 8, 1316-1327.

[S3] Yi T. F.; Xie Y.; Shu J.; Wang Z.; Yue C. B.; Zhu R. S.; Qiao H. B. Structure and Electrochemical Performance of Niobium-Substituted Spinel Lithium Titanium Oxide Synthesized by Solid-State Method, J. Electrochem. Soc. 2011, 158, A266-A274.

[S4] Tian B.; Xiang H.; Zhang L.; Wang H. Effect of Nb-doping on Electrochemical Stability of $\mathrm{Li}_{4} \mathrm{Ti}_{5} \mathrm{O}_{12}$ Discharged to $0 \mathrm{~V}$, J. Solid State Electrochem. 2012, 16, 205-211.

[S5] Wu D. Kinetic Performance of $\mathrm{Li}_{4} \mathrm{Ti}_{5} \mathrm{O}_{12}$ Anode Material Synthesized by the Solid-state Method, Ionics 2012, 18, 559-564.

[S6] Gu F.; Chen G.; Wang Z. Synthesis and Electrochemical Performances of $\mathrm{Li}_{4} \mathrm{Ti}_{4.95} \mathrm{Zr}_{0.05} \mathrm{O}_{12} / \mathrm{C}$ as Anode Material for Lithium-ion Batteries, J. Solid State Electrochem. 2012, 16, 375-382.

[S7] Yao X. L.; Xie S.; Nian H. Q.; Chen C. H. Spinel $\mathrm{Li}_{4} \mathrm{Ti}_{5} \mathrm{O}_{12}$ as A Reversible Anode Material Down to 0 V, J. Alloys Compd., 2008, 465, 375-379.

[S8] Yi T. F.; Shu J.; Zhu Y. R.; Zhu X. D.; Yue C. B.; Zhou A. N.; Zhu R. S. HighPerformance $\mathrm{Li}_{4} \mathrm{Ti}_{5-\mathrm{x}} \mathrm{V}_{\mathrm{x}} \mathrm{O}_{12}(0 \leqslant \mathrm{x} \leqslant 0.3)$ as An Anode Material for Secondary Lithium-ion Battery, Electrochim. Acta 2009, 54, 7464-7470.

[S9] Ge H.; Li N.; Li D. Y.; Dai C. S.; Wang D. L. Electrochemical Characteristics of Spinel $\mathrm{Li}_{4} \mathrm{Ti}_{5} \mathrm{O}_{12}$ Discharged to $0.01 \mathrm{~V}$, Electrochem. Commun. 2008,10, 719-722. 
[S10] Huang S. H.; Wen Z. Y.; Zhu X. J.; Lin Z. X. Effects of Dopant on the Electrochemical Performance of $\mathrm{Li}_{4} \mathrm{Ti}_{5} \mathrm{O}_{12}$ as Electrode Material for Lithium Ion Batteries, J. Power Sources 2007, 165, 408-412.

[S11] Yi T. F.; Shu J.; Zhu Y. R.; Zhu X. D.; Zhu R. S.; Zhou A. N. Advanced Electrochemical Performance of $\mathrm{Li}_{4} \mathrm{Ti}_{4.95} \mathrm{~V}_{0.05} \mathrm{O}_{12}$ as A Reversible Anode Material Down to $0 \mathrm{~V}$, J. Power Sources 2010, 195, 285-288.

[S12] Wang Z.; Chen G.; Xu J.; Lv Z.; Yang W. Synthesis and Electrochemical Performances of $\mathrm{Li}_{4} \mathrm{Ti}_{4.95} \mathrm{Al}_{0.05} \mathrm{O}_{12} / \mathrm{C}$ as Anode Material for Lithium-ion Batteries, J. Phys. Chem. Solids 2011, 72, 773-778.

[S13] Jhan Y. R.; Duh J. G. Electrochemical Performance and Low Discharge Cut-off Voltage Behavior of Ruthenium Doped $\mathrm{Li}_{4} \mathrm{Ti}_{5} \mathrm{O}_{12}$ with Improved Energy Density, Electrochim. Acta 2012, 63, 9-15.

[S14] Yi T. F.; Liu H. P.; Zhu Y. R.; Jiang L. J.; Xie Y.; Zhu R. S. Improving the High Rate Performance of $\mathrm{Li}_{4} \mathrm{Ti}_{5} \mathrm{O}_{12}$ through Divalent Zinc Substitution. J. Power Sources 2012 , $215,258-265$.

[S15] Zhang B.; Liu Y. S.; Huang Z. D.; Oh S.; Yu Y.; Mai Y. W.; Kim J. K. Urchin-like $\mathrm{Li}_{4} \mathrm{Ti}_{5} \mathrm{O}_{12}$-carbon Nanofiber Composites for High Rate Performance Anodes in Li-ion Batteries, J. Mater. Chem. 2012, 22, 12133-12140.

[S16] Chen J. Z.; Yang L.; Fang S. H.; Hirano S.; Tachibana K. Synthesis of Hierarchical Mesoporous Nest-like $\mathrm{Li}_{4} \mathrm{Ti}_{5} \mathrm{O}_{12}$ for High-rate Lithium Ion Batteries, J. Power Sources 2012, 200, 59-66.

[S17] Wang C.; Wang S.; Tang L.; He Y. B.; Gan L.; Li J.; Du H.; Li B.; Lin Z.; Kang F. A Robust Strategy for Crafting Monodisperse $\mathrm{Li}_{4} \mathrm{Ti}_{5} \mathrm{O}_{12}$ Nanospheres as Superior Rate Anode for Lithium Ion Batteries, Nano Energy 2016, 21, 133-144. 